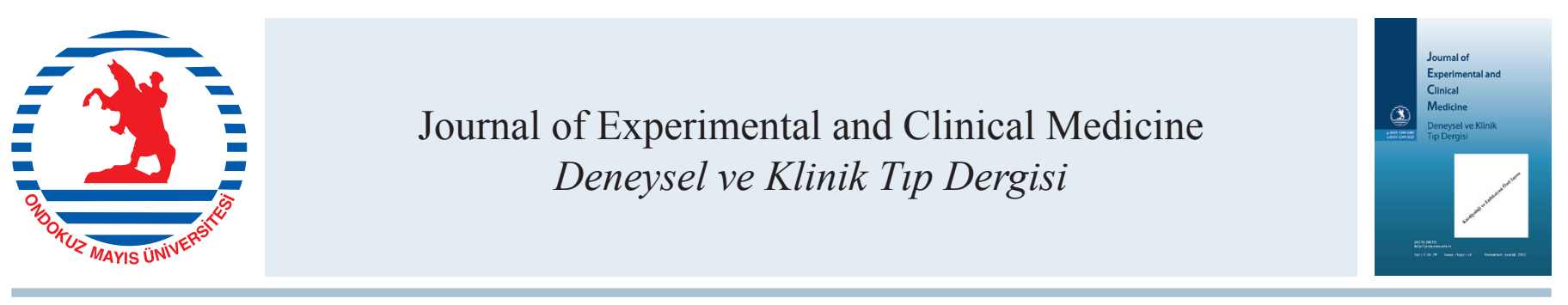

Derleme / Review

doi: $10.5835 /$ jecm.omu.29.s3.002

\title{
Ateroskleroz patogenezi
}

\section{Pathogenesis of atherosclerosis}

\section{Halit Zengin}

Ondokuz Mayıs Üniversitesi, Tıp Fakültesi, Kardiyoloji Anabilim Dall, Samsun, Türkiye

\begin{tabular}{|c|c|}
\hline MAKALE F & GİLERİ \\
\hline Makale geçı & \\
\hline Geliş tarihi & : $30 / 06 / 2011$ \\
\hline Kabul tarihi & : 05 / 07 / 2011 \\
\hline
\end{tabular}

\section{Yazışma Adresi:}

Halit Zengin

Ondokuz Mayıs Üniversitesi

Tip Fakültesi,

Kardiyoloji Anabilim Dalı,

Samsun, Türkiye

e-posta: halitzengin@omu.edu.tr

\author{
Anahtar Kelimeler: \\ Ateroskleroz patogenezi \\ Endotel disfonksiyonu \\ Dislipidemi \\ Plak \\ LDL \\ İskemi
}

\section{Keywords:}

Pathogenesis of atherosclerosis

Endothelial dysfunction

Dyslipidemia

Plaque

LDL

Ischemia

\section{ÖZET}

Dünyada ve ülkemizde ateroskleroz ve komplikasyonları en önde gelen ölüm nedenidir. Ateroskleroz, tipik lezyonu ateroma plakları olan orta ve büyük çaplı arterlerin intima tabakaların etkileyen bir hastalıktır. Aterosklerozun başlamasında endotel disfonksiyonu major rol oynamaktadır. Aterosklerozun risk faktörlerinin ortak noktası endotel disfonksiyonudur. Düşük dansiteli lipoproteinin (LDL) endotel altına geçmesiyle birlikte salınan bir takım sitokinler ve kemotaktanların etkisiyle enflamatuvar hücreler intimada birikmeye başlar. Makrofajların intimada okside LDL'yi fagosite etmesiyle birlikte köpük hücresi oluşur ve intima altında sarı çizgilenmeler olarak gözlenir. Lümende darlık oluşturmayan bu lezyonlar yağlı çizgilenme olarak adlandırılır ve aterosklerozun ilk lezyonudur. Köpük hücrelerinin apopitosisi ile nekrotik lipid çekirdek oluşur. Mediadan intimaya göç eden düz kas hücrelerinin proliferatif özellik kazanması ile birlikte lipid çekirdek etrafında ekstrasellüler bağ dokusu (kapsül) sentezi başlar. Lipit çekirdek ve etrafinda fibröz kapsülü olan, lümeni daraltan lezyona fibröz plak denir. Lipit çekirdeğin büyüyüp kapsülün incelmesi ve enflamatuvar hücrelerin çoğalması ile birlikte unstable plak oluşur. Plak kapsülünün yırtılıp plak içeriğinin kan ile teması sonucu plak üzerine trombüs ve fibrinin bindiği komplike lezyon meydana gelir. Ateroskleroz endotel disfonksiyonu, dislipidemi ve enflamatuvar hücrelerin merkezi rol oynadığı, birçok risk faktörünün tetiklediği kronik inflamatuvar bir hastalıktır.

J. Exp. Clin. Med., 2012; 29:S101-S106

\section{ABSTRACT}

Atherosclerosis and its complications are the leading cause of death both in our country and the world. Atheroma plaques are the typical lesion of atherosclerosis and affect intimal layers of medium and large arteries. Endothelial dysfunction plays a major role in the initiation of atherosclerosis. Endothelial dysfunction is a common point in risk factors of atherosclerosis. Inflammatory cells begin to accumulate in intima by the effect of cytokines and chemokines secreted with passage of LDL (low-density lipoprotein) through endothelium. Foam cells are formed as a result of phagocytosis of LDL by macrophages and seen as yellow streaks under the intima. Those lesions are first lesions of atherosclerosis and do not cause stenosis and termed as fatty streaks. The necrotic lipid core is formed by apoptosis of foam cells. Extracellular connective tissue (capsule) synthesis begins around the lipid core by proliferation of smooth muscle cells that migrate to intima. Fibrous plaque is a lesion with a fibrous capsule around the lipid core and narrows the lumen. Unstable plaque is formed by proliferation of inflammatory cells and thinning of capsule through enlargement of lipid core. Tear of plaque capsule and contact of plaque content with blood results in formation of a complicated lesion in which thrombus and fibrin bind on plaque. Atherosclerosis is a chronic inflammatory disease in which endothelial dysfunction, dyslipidemia and inflammatory cells play a central role and triggered by many risk factors.

J. Exp. Clin. Med., 2012; 29: S101-S106

(C) 2012 OMU
Giriş

Gelişmiş ülkelerde ateroskleroz komplikasyonları ile birlikte önde gelen morbidite ve mortalite nedenidir. Türkiye'de Erişkinlerde Kalp Hastalığı ve Risk Faktörleri 
Sıklığı Taraması (TEKHARF) verilerine göre ülkemizde koroner arter hastalığı (KAH) prevalansı 45-54 yaş grubunda $\% 6$ iken, 55-64 yaş grubunda \%17 dolayına, 65 yaş ve üzerindeki bireylerde $\% 28$ düzeyine yükselmektedir. Söz konusu prevalanslar 1990 yılındakilere kıyasla 50 yaş üstü kesimde $\% 80$ oranında artmıştır. Ülkemizde yine TEKHARF çalışmasının verilerine göre tüm ölümlerin $\% 42$ 'sikoroner kalp hastalığına, \%10'u da serebrovasküler hastalıklara bağlıdır (Onat, 2009). Bu iki veriyi birleştirirsek ateroskleroza bağlı ölümler hemen hemen tüm ölümlerin yarısından sorumlu gibi gözükmektedir (Șek. 1).

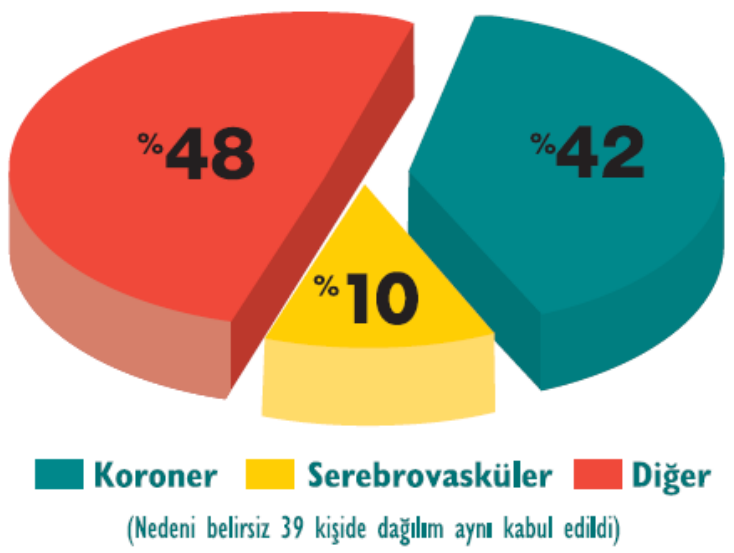

Şek. 1. TEKHARF'de ölüm sebebi dağılımı (1990-2008, $\mathrm{n}: 568)$

Arteriosklerozun üç tipi vardır;

1-Ateroskleroz: Arteriosklerozun üç tipinden en yaygın ve en tehlikeli formudur. Bu iki terim bazen birbirlerinin yerine kullanılabilirler.

2-Mönkeberg'in medial kalsifik sklerozu: Medianın kalsifik dejenerasyonu olarak da adlandırılan ve orta boy arterlerin media tabakasının kalsifikasyonu ile seyreden bir hastalıktır.

3-Arteriloskleroz: Küçük arterleri ve arteriolleri etkileyen hiyalin ve hiperplastik olarak iki tipi bulunan hipertansif veya diyabetik hastalarda damar tutulumunu ifade eden bir hastalıktır.

Biz yazımızda en yaygın ve klinik olarak en tehlikeli form olan aterosklerozdan bahsedeceğiz.

Önceden damar yatağının kanı kalpten dokulara ulaştıran bir boru sistemi olduğuna inanılırdı. Günümüzde önceden inanıldığının aksine vasküler yapılar biyolojik olarak etkin çok farklı fonksiyonları olan bir yapı olarak bilinmektedir. Ayrıca aterom plaklarının sadece damar lümenini daraltan yă̆ ve bağ dokusundan oluşan yapılar olmadığı damar yapılarında bulunan hücreler, inflamatuar hücreler ve salgılanan birçok maddenin etkisiyle plak yapısının çok aktif dinamik bir oluşum olduğu bilinmektedir.

Hastalığın tedavisinde koroner anjiyoplasti ve by-pass cerrahisi ile semptomatik lezyonları hedefleyen girişimsel işlemler tedavide baskın olmuştur. Ancak aterosklerotik plakların hücresel yapısının farklı olduğu ve plakta bulunan hücre tipinin fatal klinik olay riskini belirleyebileceğinin ortaya konulması, inflamatuar hücreler ve mediatörlerin ateroskleroz patogenezindeki rolünün anlaşılması ve büyük klinik çalışmaların HMG-CoA redüktaz inhibitörlerinin aterosklerotik plak boyutunu etkilemeden klinik olay sayısını azaltabileceğinin gösterilmesiyle yukarıda bahsedilen baskın tedavi anlayışı değişmiştir.

Aterosklerozun irreversibl olarak ilerleyen bir hastalıktan ziyade tıbbi tedaviye yanıt verebilen, dinamik inflamatuar bir süreç olduğu ortaya konulmuştur. Ayrıca aterosklerozun klinik sonuçlarının lümen daralmasından ziyade plağın içeriğine odaklanan yeni tanısal yaklaşımları gündeme getirmiştir.

Ateroskleroz primer olarak orta ve büyük boyuttaki elastik arterlerin intima tabakasını etkileyen, karakteristik lezyonu plak olan ve asemptomatik yağlı çizgilenmelerden damar lümenini daraltan stabil veya komplike lezyonlara kadar değişik formları olan kesintisiz bir süreçtir.

\section{Normal arter duvarı}

Normal arter duvarı; intima, medya ve adventisya olmak üzere üç tabakadan oluşmaktadır.

İntima tabakası, lümene bakan yüzde tek sıra dizilmiş endotel hücreleri, bunları destekleyen subendotelyal matriks ve bazal memran intimayı oluşturur. Tek katlı endotel, tip-4 kollajen gibi fibriler olmayan kollajen tiplerini, laminin, fibronektin ve diğer ekstra selüler matriks moleküllerini içeren bir bazal lamina üzerine oturur. İntima tabakası elastik lifçiklerin yoğunlaşması ile meydana gelen membrana elastika interna ile medya tabakasindan ayrılır. Doğumda sadece bir kaç mikrometrelik bir kalınlığa sahip olan intima tabakas1, yaşam boyunca, tip-1 ve tip-3 gibi fibriler kollajen doku, proteoglikanlar ve mezenşim hücrelerinin birikmesiyle, giderek kalınlaşır. Mezenşim hücreleri, "modifiye" düz kas hücrelerine benzerler ve fibroblastlar gibi görev yaparlar. Arteriyel ağacın dallanma bölgelerinde, düz kas hücrelerinin çoğalmasına bağlı olarak, intima kalınlığ ve endotel geçirgenliği artar; medya hücrelerinin tabakasal yapılanması bozulur ve yastıkçıklar gelişir. Bu bölgeler, hücre bölünmesi ve doku yenilenmesi açısından sıcak noktalar olup, damar kök hücreleri içerirler. İntima kalınlığının en fazla olduğu bölgeler yukarıda bahsedilen nedenlerden dolayı arterlerin çatallanma bölgeleri ve yan dalların ağız bölgeleridir. Ancak bu durum damar lümenini kesinlikle daraltmamaktadır. Ancak şu da unutulmamalıdır ki ateroskleroz en çok bu bölgelerde yerleşmektedir. $\mathrm{Bu}$ intima kalınlaşmalarını aterosklerozun ön değişiklikleri kabul etmek yerine ateroskleroz için yatkın bölgeler olarak değerlendirmek daha doğru olacaktır. Ateroskleroza en yatkın arterler; sol ana koroner arterin, karotis arterlerin ve distal abdominal aortun dallanma noktalarıdır.

Medya tabakası, arter duvarının orta ve en kalın tabakasıdır. Kollajen elastik lifler ve glikozaminoglikanlardan oluşan matriks içinde konsantrik olarak dizilmiş düz kas hücrelerinden oluşur. Damar duvarında bulunan düz kas hücrelerinin tamamına yakını bu tabakada yer almaktadır. Damar düz kas hücreleri fibroblast benzeri hücrelere dönüşebilme yeteneğine sahiptir. Damar tonusunu salgılanan bir kısım mediatörlerle medya tabakası sağlar. Adventisya tabakası, en dış tabakadır. Gevşsek bağ dokusu yapısındaki bu tabaka kollajen liflerden vasovazorumlardan ve sinir uçlarından oluşur (Vallace, 1996). İntima ve medya tabakasına göre seyrek hücre dağılımına sahiptir.

\section{Aterosklerozda rol alan hücreler}

Endotel hücreleri, damarın kanla temas eden kritik yüzeyini oluşturmaktadır ve hemostazda çok iyi düzenlenen 
çok önemli mekanizmalara sahiptir. Endotelyum çok önemli antiinflamatuvar ve antikoagulan özellikleri nedeniyle normal fizyolojinin işlemesinde merkezi rol oynar. Normal endotelin 3 önemli fonksiyonu vardır:

1- Kan doku geçirgenliğini belirlemek

2- Hemostazla ilgili damar yüzey özelliklerini belirlemek

3- Pek çok vazoaktif madde salgılayarak damar tonusu ve bağ dokusu yapımını kontrol etmek

Endotel hücreleri arasındaki bağlar normalde albüminden daha büyük moleküllerin geçişine izin vermeyecek kadar sıkıdır. Lipoproteinler albüminden çok daha büyük olduğundan endotel engelini ancak transsitoz ile geçerler. $\mathrm{Bu}$ mekanizma lipoprotein reseptörlerinden bağımsızdır ve kandaki lipoprotein düzeyleri ile ilişkilidir. Endotel zedelendiğinde bu engel özelliğinin bozulduğu ve lipoproteinlerin subendotelyuma geçişinin hızlandığı öne sürülmüştür (Erol, 2004).

Hasar görmemiş endotel, salgıladığı nitrik oksit ve prostosiklin (PGI2) bağlı olarak ve heparin sülfat ile kaplı olması nedeniyle trombüs oluşumuna dirençli bir yüzeydir.

Endotelin özelliklerinin birçoğu nitrik oksit (NO) molekülü aracılığı ile olur. NO endotelyal bir enzim olan nitrik oksit sentetaz aracılığ ile L-argininden sentezlenir. NO endotel hücreleri üzerinde trombosit agregasyonunun güçlü bir inhibitörü ve vasküler tonusu azaltarak vazodilatasyona sebeb olan güçlü bir vazodilatatördür. Ayrıca antiinflamatuvar özelliği ile aterosklerozu her evrede engelleyici etki gösterir. $\mathrm{Bu}$ etkisini inflamasyona sebep olan intersellüler adezyon molekülü-1 (ICAM-1), vasküler hücre adezyon molekülü-1 (VCAM-1), makrofaj kemotaktik protein-1 (MCP-1), P selektin gibi moleküllerin sentezini sağlayan genlerin ekspresyonunu engelleyerek gösterir. Nitekim aterosklerozu kolaylaştırdığı bilinen hipertansiyon (HT), diyabetes mellitus (DM), sigara içilmesi ya da süper oksit düzeyinin artış1 gibi durumlarda endotelden NO yapımının azaldığı ya da yıkımının arttığı gösterilmiştir (Li, 2000).

Endotel hücreleri trombosit agregasyonu inhibitörü ve kuvvetli bir vazodilatatör olan ve fibrin yıkııı ürün olan plazminojen salınımından sorumludur.

Düz kas hücreleri, normalde damar duvarının medya tabakasında bulunur ve damar tonusundan sorumludur. Medyadaki düz kas hücreleri çok sayıda kontraktil protein içerir. Ateroskleroz sürecinde düz kas hücreleri medyadan intimaya göç ederler ve kontraktil protein içeriğinde azalma ve sentetik organel sayısında artma meydana gelir. İntimaya göç eden kas hücreleri kontraktil fenotipten sentetik fenotipe dönüşür ve proliferasyonda rol alırlar. Medyadaki düz kas hücreleri endotelin, ketokolamin, anjiotensin II gibi vazokonsiktorlere ve nitrik oksit ve PGI2 gibi vazodilatatörlere cevap verirken intimadaki düz kas hücreleri platelet derived growth factor (PDGF) gibi mitojenlere cevap verir. Son zamanlarda bu hücrelerin aterosklerozda yıkıcı bir rolden ziyade yapıcı onarıcı bir rol aldığı düşünülmektedir. Damarı tamir etmek ve plağın lipidden zengin çekirdeğinde fibröz şapka oluşturmak için gerekli olan glikozaminoglikan, elastin ve kollojen gibi matriks proteinlerini büyük miktarda üretirler. Plak kapsülü içeriğini sentezleyerek aterosklerotik lezyona stabilite kazandırır ve trombojenik olan lipidden zengin plak çekirdeğini trombositlerden ve pıhtılaşma kaskadı proteinlerinden ayırır. Vasküler düz kas hücreleri plak stabilitesinde ve fatal trombojenik sonuçları engellemede önemli rol oynarlar (Libby, 1995).

\section{Enflamatuar hücreler}

Makrofajlar dolaşımdaki monositlerden türeyen hücrelerdir. Monositi kandan intimaya çeken güç okside LDL partiküllerinin uyarıcılığı ile salınan kemotaktanlardır. Bunların başında da endotel hücreleri, düz kas hücreleri ve makrofajlar tarafindan salınan MCP-1 gelir (Farugi ve Di Carleto, 1993). Makrofaj koloni sitümüle edici faktör (MCSF) etkisiyle monositler makrofajlara dönüşür. Endotel disfonksiyonu ile birlikte reseptör görevi yapan adezyon molekülleri endotel hücresinde belirmeye başlar.

\section{Adezyon molekülleri başlıca 4 grupta ele alınır.}

1. İmmunglobulin gen ailesi

-(VCAM-1)

-(ICAM-1, ICAM-2)

-Platelet/endothelial cell adhesion molecule

(PECAM)

2. Glikoprotein yapısında

- 1 integrinler

- 2 Lökosit integrinleri

- 3 Glikoprotein IIb/IIIa

3. Selektinler

- E-selektin (endotel hücresinde)

- P-selektin (trombosit üzerinde)

- L-selektin (lokosit üzerinde)

\section{Kadherinler}

VCAM-1 dolaşan monosit ve T lenfositler için endotel hücresinde reseptör görevi yaparlar. Monositler ve $\mathrm{T}$ lenfositler ise, karşı reseptör ve bir integrin olan çok geç aktivasyon antijen-4 (VLA-4)'ü taşırlar. VLA-4, VCAM1 'e bağlanabilir. Adezyon moleküllerinin en çok bulunduğu bölgeler kanın laminar akımının bozulduğu bölgelerdir ki bu bölgeler zaten ateroskleroza yatkın bölgeler olarak bilinmektedir (Nagel ve ark., 1994; Topper ve ark., 1996).

Selektinler, endotel üzerinde, lökositlerin sıçrama ya da yuvarlanma şeklindeki hareketlerini uyarır.

Glikoprotein yapısındaki integrinler hücrelerin birbirlerine veya çevredeki yapılara sıkıca tutunmasını sağlar.

Köpük hücrelerini oluşturan asıl hücreler makrofajlardır. LDL'nin oksidasyonu makrofajlar tarafindan tamamlanır. LDL üzerindeki apo B proteini makrofajlar üzerindeki scavenger (çöpçü) reseptörler tarafından tanınacak şekle dönüşür. Daha sonra makrofajlar scavenger reseptörleri vasitasıyla okside LDL'yi fagosite ederler.

\section{Ateroskleroz süreci}

\section{Endotel disfonksiyonu}

Endotel disfonksiyonu aterosklerozun patogenezinde ilk temel basamağı oluşturur. Ross tarafından hasara tepki hipotezine göre olayları endotel disfonksiyonu başlatır (Ross, 1993). Metabolik, mekanik, toksik, immünolojik olaylar endotel disfonksiyonuna neden olurlar. Bilinen risk faktörlerinin hemen hepsi (sigara, hipertansiyon, diyabet, hiperkolesterolemi) endotelde fonksiyon bozukluğuna neden olabilir. Disfonksiyon ile tek sıra dizili endotel hücrelerinin seçici geçirgen özelliği ve antitrombotik yüzey özelliği bozulur. Ayrica vazodilatasyondan vazokonstriksiyon 
tarafina, antitrombotik özellikten protromboz tarafina, antiproliferatif özellikden proliferatif özellik tarafına denge bozulur (Koeng, 1999). Disfonksiyone aktive olmuş endotel hücrelerinden adezyon molekülleri, sitokinler (IL-1, TNF- $\alpha$ ), kemokinler (MCP-1, IL-8) ve büyüme faktörleri (PDGF, FGF) salgilanır.

\section{Hücre dışı lipit birikimi ve LDL'nin oksidasyonu}

Kronik hiperlipidemi ile birlikte kolesterol doymuş yağ ve düşük dansiteli lipoproteinler intima içinde birikmeye başlarlar. Lipoprotein partikülleri intima içinde proteoglikanlara bağlanarak intimada kalış süresi uzamaktadır (Camejo ve ark., 1998; Williams ve Tabas, 1998). Bu uzama LDL'nin oksidasyonuna olanak sağlar. Makrofajlarda LDL reseptör sayısı az olduğundan okside olmamış LDL fagositoz hızı düşüktür. LDL endotel, düz kas hücreleri ve makrofajlar tarafından okside edilir ama ilk başta yapısındaki apo B-100 değişmez buna minimal modifiye LDL denir. Bu LDL yine LDL reseptörü tarafından tanındıkları için köpük hücre oluşumuna katkı sağlamazlar ancak MCP-1 salınımını uyararak ortama daha fazla monosit toplanmasını sağlarlar. Oksidasyonu tamamlanmış LDL'nin yapısındaki apo B-100 de değişmiştir ve makrofajların çöpçü reseptörleri ile yoğun bir şekilde fagosite edilebilecek hale gelir. Okside LDL kemokinlerin sitokinlerin adezyon moleküllerinin ve büyüme faktörlerinin salgılanmasını uyarır.

\section{Lökositlerin bir araya toparlanması}

Normal endotel hücresi lökositlerin adezyonuna direnç gösterir. Endotel yüzeyinde adezyon moleküllerinin ekspresyonu monositler ve $\mathrm{T}$ lenfositlerin endotele adezyonunu sağlamaktadır. Adezyon moleküllerinin başında immünglobülin üst ailesinden olan VCAM-1 ve 2 gelmektedir. Diğer bir lökosit adezyon kategorisini selektinler oluşturur. Selektinler endotel hücresinde lökositlerin siçrayan veya yuvarlanma tarzı hareketini teşvik etme eğilimi gösterirken immünglobülin ailesine ait olan adezyon molekülleri daha sık1 adeziv etkileşimi ve lökositlerin hareketsizleşmesini teşvik etme eğilimindedir.

Adezyondan sonra lökositlerin intima içine girmesi için bir sinyal gerekmektedir. Bu sinyali kemokin olarak bilinen maddeler sağlar. Okside olmuş LDL'nin uyarması ile endotel ve düz kas hücreleri dahil bir çok hücre tarafından salgılanan monositleri çeken protein olan MCP-1 salgılanır. MCP-1 monositlerin seçici yönlendirilmiş göçünü sağlamaktadır. Lökositler üzerindeki CXCR2'e bağlanan bir molekül olan interlökin-8 de deneysel ateroskleroz oluşumunda rol oynamaktadır (Zipes, 2005).

\section{Hücre içi lipit birikimi ve köpük hücre oluşumu}

Makrofajlar okside LDL'yi fagosite ederek kolesterolü içerisinde biriktirir ve aterosklerozun prototip hücresi olan köpük hücresine dönüşür. Klasik LDL reseptörü köpük hücre birikimini düzenlememektedir. Makrofajlar normal LDL'yi önemli miktarda fagosite edemezler. Ancak makrofajlar çöpçü reseptörler aracılığg ile okside LDL'yi büyük oranda fagosite edebilirler. Makrofajlar okside LDL'yi fagosite ettikten sonra parçalarlar ve kolesterol esterleri şeklinde depo ederler. Kolesterol esterleri hücre içinde yağ damlacıkları oluşturmaya başlar ve makrofaj lipit yüklü köpük hücresine dönüşünceye kadar devam eder. Makrofaj yüzeyindeki çöpçü reseptörlerde down regülasyon olmadığından depolama işlemi köpük hücresinin apoptozisine kadar devam eder.

\section{Aterosklerotik lezyonlar \\ Yağlı çizgilenme}

Çok sayıda köpük hücresinin intimada birikmesi ile oluşur. Erken yaşlarda bile gözlenebilen ateroskleroz lezyonudur. Makroskopik olarak bakıldığında damar lümeninde kan akımı yönünde sarı çizgiler olarak görülürler. Kan LDL düzeyi azalması ile birlikte lezyona göç eden lipid miktarı azalır ve çıkan lipid miktarı artar böylece lezyon geriler ve yerinde sadece skatriks dokusu kalır. Eğer tersi olursa lezyon bir ileri lezyona ilerler (Fuster ve Fayad, 1999).

\section{Fibröz plak}

Makroskopik olarak çoğunlukla lümene doğru büyüyen beyaz renkli lezyonlardır. Mikroskopik olarak lipit çekirdek, büyük miktarda düz kas hücreleri, makrofajlar, köpük hücreleri, T lenfositler ve ekstra sellüler matriks bulunur.

Lezyonlar ilerledikçe hücre dışı lipit birikmeye başlar. Hücre dışı lipit havuzunun büyük miktarını köpük hücrelerinin apaptosizi sonucu köpük hücrelerinde depolanan kolesterol esterlerinin açığa çıkması oluşturur. Çok az kısmını ise lümenden geçen lipoproteinler oluşturur (Erol, 2004). Makrofajların sürekli çoğaldıkları ve monositlerin de sürekli lezyon içine göçtükleri göz önüne alındığında makrofaj sayısının aşırı artmaması apopitosis görüşünü desteklemektedir. Plakda lipit çekirdek etrafında metalloproteazları üreten makrofajlar bulunmaktadır.

Olgunlaşan aterom plağında lipit çekirdeğin üzeri fibröz başlık ile örtülüdür. Fibröz başlık medyadan intimaya geçen düz kas hücreleri ve onların ürettiği bağ dokusundan (kollajen lifleri, elastin, preteoglikanlar ve glikozaminoglikanlar) oluşur. Düz kas hücrelerinin göçü ve proliferasyonu PDGF, FGF gibi büyüme faktörlerinin uyarısı ile gerçekleşir. Düz kas hücreleri ekstrasellüler matriks yapma yeteneğinde olan onarıcı hücrelerdir.

Fibröz başlıkta bir yandan düz kas hücreleri tarafından ekstrasellüler matriks yapımı devam ederken diğer taraftan makrofajlar tarafindan üretilen proteinazlar tarafından bağ dokusu yıkımı olmaktadır. Bu yapım ve yıkım çok sayıda sitokin tarafindan kontrol edilmektedir.

Fibröz plaklar damar lümenini anlamlı bir şekilde daraltsalar bile sağlam kaldıkları sürece önemli klinik olaylara yol açmadıklarına inanılmaktadır. Fibröz başlık ne kadar kalınsa plak o kadar stabildir. Lipit ve inflamatuar hücrelerden zengin ve ince fibröz kapsüle sahip plaklar yüksek yırtılma, zedelenme riskine sahiptir (vulnarable plak).

\section{Komplike lezyonlar}

Lipit, enflamatuvar hücre ve fibröz dokuya ek olarak hematom, hemoraji ya da trombüs içeren plaklardır. Komplike olmaya aday plaklara kararsız, unstable veya vulnarable plaklar denir.

Unstable plaklar plak hacminin en az yarıya yakınını oluşturan büyük lipit çekirdek, çok sayıda inflamasyon hücresi, düz kas hücresi ve kollajen içeriği azalmış ince fibröz kapsül ve çevresinde artmış çevresel stres ile karakterizedir (Erol, 2004). Kararsız plakların yaralanmaya en açık bölgeleri fibröz kapsülün damar duvarı ile birleştiği omuz bölgeleridir.

Lipid çekirdeğin etrafındaki makrofajlar tarafından 
salgılanan metalloproteinazlar (kollajenaz,elastaz,stromelizin) denen enzimler fibröz kapsülün kollajen içerikli matriksini parçalar. Ayrıca aktive olmuş makrofajlardan salınan IL-1 $\beta$, TNF $\alpha$ ve T lenfositlerden salgilanan INF- $\gamma$ sinerjistik etki göstererek düz kas hücrelerinin ölümüne ve ekstrasellüler matriks azalmasina neden olur. Bir yandan yıkımın artması diğer yandan yapımın azalması ile fibröz kapsül zayıflar ve en sonunda çatlar. Fibröz başlığı hasarlaşmış plakta prokoagulan maddeler kan elemanları ve pıhtılaşma faktörleri ile karşılaşıp trombüs oluşumu tetiklenir. Plak rüptürü ve trombüs oluşumu ile birlikte akut koroner sendromlar denilen klinik olaylar başlamış olur. Aterom plağın rüptüre olması için damar lümenini önemli miktarda daraltması gerekmez. Lümeni ciddi manada daraltmayan yukarıda bahsedilen unstabil plaklarda rüptüre olarak akut koroner sendromlara neden olabilirler.

Amerikan Kalp Birliği (American Heart Association, AHA) lezyonların ilerleme sürecini 8 farklı evreye ayırmıştır. $\mathrm{Bu}$ yeni sınıflama morfolojik değişiklikleri klinik sonuçlarla birleştirerek konunun anlaşılmasını kolaylaştırır (Hansson ve Nilsson, 2010; Avsar ve ark., 2011).

Tip I lezyon, az lipid ve seyrek köpük hücreleri bulundurur. Tip I lezyonlar genellikle adaptif intimal kalınlaşmalarla aynı yerleşime sahiptirler.

Tip II lezyonlarda, köpük hücreleri oldukça artmış olup, yağlı çizgilenmeyi oluştururlar. Bu lezyonlarda seyrek $\mathrm{T}$ hücreleri, mast hücreleri ve lipid dolu düz kas hücreleri de bulunabilir. Bu lezyonların bir bölümü geriler veya yaşam boyu değişmez ancak bir kısmı tip III lezyona ilerler. Tip II lezyonlar da, adaptif intimal kalınlaşmalar ile aynı yerleşimde olma eğilimindedirler.

Tip III lezyon, klasik patolojide aterosklerotik plak veya aterom olarak kabul edilen ilk lezyon evresidir. Tip II lezyondan en önemli farkı, makrofajların ve T hücrelerinin altında, lezyonun daha derin bölgelerinde, az da olsa hücre dişı lipid birikimlerinin başlamasıdır. Tip III lezyonların, gelecekteki klinik hastalığın öngördürücüsü olduklarına inanılır.

Tip IV lezyonlarda, artan hücre dışı lipidler kolesterol havuzu oluştururlar. Lipidler, yıkılan köpük hücrelerinden gelebilir ya da lipoproteinlerin doğrudan birikimleri söz konusu olabilir. Lipid çekirdek, enflamatuvar hücreler ile çevrelenir. Düz kas hücreleri ve bağ dokusu, ince bir tabaka halinde bu lipid çekirdeği kaplar. Adventisyadaki vazo vazorumlardan kaynaklanan kılcal damarlar, plağın daha derin bölümlerine doğru ilerlemeye başlar. Tip IV lezyonlarda, adaptif intimal kalınlaşma bölgelerinde gelișirler. Bu lezyonlar, genellikle hilal şeklindedirler ve bir çatallanma bölgesinde akımı bölen karşıt arter duvarının kalınlığını arttırırlar. Bu evrede arter, ilk lümen hacmini koruyabilmek için yeniden biçimlenir ve damarın dış sınırı ovalleşir. Tip IV lezyonu anjiyografi ile göstermek zordur. Klinik olarak sessiz olsalar da, yırtılma potansiyelleri nedeniyle intravasküler ultrasonografi, manyetik rezonans gibi değişik görüntüleme yöntemleriyle tanınmaları önemlidir. Son anjiyografik değerlendirmesi normal olan bir koroner arterde, tıkanıklık ya da anlamlı bir darlık geliştiğinde en muhtemel açıklama, yırtılmış tip IV lezyon üzerinde trombüs gelişimidir.

Tip V lezyonlarda, lipid çekirdeği örten fibröz doku artmıştır. Bu fibröz doku artışı, düz kas hücrelerine bağlıdır. Düz kas hücreleri, çoğalırlar ve kollajen ve proteoglikanlar gibi ekstrasellüler matriks proteinlerini salgılarlar. İnsan arter intiması, normalde bir miktar düz kas hücresi içerir. Tip V lezyonlarda fibröz dokuyu oluşturan düz kas hücrelerinin, medyadan mı geldikleri ya da önceden var olan intimal hücreler mi oldukları konusu açık değildir. Kollajen, tip V lezyonların baskın unsurudur. Kılcal damarların lezyon içindeki gelişimleri, tip IV lezyona göre daha belirgindir. Tip V lezyonlar, yeniden biçimlenme ile dengelenemeyecek kadar büyük olduklarından, arter lümenini daraltırlar ve anjiyografi ile görüntülenebilirler. Klinik olarak angina pektorise neden olabilirler. Tip V lezyonlar sıklıkla lümene yayılırlar ve laminer kan akımını bozarlar.

Tip VI lezyonlar, trombüs ya da hemoraji odakları içeren komplike plaklardır. Tip VI lezyon gelişiminin ana nedeni, plak yırtılmasıdır. Bu tip lezyonlarda endotel altı fibröz dokunun fissür, erozyon ve ülserasyonlarına da sık rastlanır. Tip VI lezyonlar, vazo vazorumlardan plak içine ulaşan kılcal damarların kanaması sonucu da oluşabilirler. Akut koroner sendromlar, az bir istisna dışında tip VI lezyona bağlıdırlar. Ancak, tip VI lezyonlar klinik semptomlar olmaksızın da gelişebilir. Yırtılmış plak üstünde gelişen trombüslerin çoğu fibrinolitik sistem tarafından kaldırılır, ancak bir kısmı plak içine girebilir. $\mathrm{Bu}$ süreç, anjiyografi ile gösterilebilir; hızlı plak ilerlemesinden sorumludur. Trombotik materyal, düz kas hücreleri tarafından fibröz dokuya dönüştürülür ve bu iyileşme süreci sonunda lezyon, tip V morfolojisine geri döner.

Tip VII ve tip VIII lezyonlar, lipid içermez ya da çok az lipid içerir. Tip VII lezyonlar kalsiyumdan, tip VIII lezyonlar ise kollajenden zengindir. Bu lezyonların, hastalığın son evresini oluşturduklarına inanılır. Kalsifikasyon, 69 yaş üzeri bireylerin koroner arterlerinde yaygın olarak bulunur. Kalsifikasyon, genellikle plak büyümesine etki etmez. Klinik önemi de açık değildir, ancak lezyonların esnekliğini azaltıp, onları gerilme kuvvetlerine daha duyarlı hale getirebilir. Tip VIII lezyonlar, tip V ve VI lezyonlardan daha kararlıdırlar.

\section{KAYNAKLAR}

Avşar, A., Akci, A., Beyter, M.E., 2011. Aterosklerozun patogenezi. Turkiye Klinikleri J. Cordiol. Special Topics. 4 , 5.

Camejo, G., Hurt-Camejo, E., Wiklund, O., Bondjers, G., 1998. Association of apo B lipoproteins with arterial proteoglycans: Pathological significance and molecular basis. Atherosclerosis. 139, 205-222.

Hansson, G.K., Nilsson, J., 2010. Pathogenesis of Atherosclerosis. In: Crawford, M.H., Di Marco, J.P., Paulus, W.J., eds. Cardiology. 3rd Ed. Philadelphia. Mosby Elsevier, 3-15.

Erol, Ç., 2004. Klinik Kardiyoloji. Medikal \& Nobel Tıp Kitap Saray1. 3, 9-15.

Farugi, R.M., Di Corleto, P.E., 1993. Mechanisms of monocyte recruitment and accumulation. B.H.J. 69, 19-29.

Fuster, V., Fayad, A.Z., Badimon, J.J., 1999. Acute coronary sendromes: Biology. Lancet. 353, 5-9.

Koeng, W., 1999. Athersclerosis involves more than just lipids: Fcus on inflammation. Eur. Heart. J. 19-26.

Li, H., Forsterman, U., 2000. Nitric oxide in pathogenesis of vascular disease. J. Pathol. 190, 244-254.

Libby, P., 1995. Molecular bases of the acute coronary syndromes. Circulation. 91, 2844-2850.

Nagel, T., Resnick, N., Atkinson, W.J., Dewey, C.F., Gimbrone, M.A., 1994. Shear stress selectively upregulates intercellular adhesion mole- 
cule-1 expression in cultured human vascular endothelial cells. J. Clin. Invest. 94, 885-891.

Onat, A., 2009. TEKHARF çalışması 2009. Figur grafik ve matbaacılık Tic. Ltd. Şti. İstanbul. 24.

Ross, R., 1993. The pathogenesis of atherosclerosis. Nature. 362, 801-809.

Topper, J.N., Cai, J., Falb, D., Gimbrone, M.A. Jr., 1996. Identification of vascular endothelial genes differentially responsive to fluid mechanical stimuli: Cyclooxygenase-2, manganese superoxide dismutase, and endothelial cell nitric oxide synthase are selectively up-regulated by steady laminar shear stress. Proc. Natl. Acad. Sci. U.S.A. 93, 10417-10422.

Vallace, P., 1996. Vascular endothelium, its physiology and pathophysiology. In: Weatherall DJ et al. Oxford text book of medicine, 3rd ed. Oxford Medical Publications. 2, 2295-2300.

Williams, K.J., Tabas, I., 1998. The response-to-retention hypothesis of atherogenesis reinforced. Curr. Opin. Lipidol. 9, 471-474.

Zipes, D.P., Libby, P., Bonow, R.O., Braunwald, E., 2005. Braunwald's heart disease: A textbook of cardiovascular medicine. 925. 